\title{
Budżet partycypacyjny \\ - źródło inspiracji i przemian \\ dla demokracji uczestniczącej \\ (na przykładzie budżetu \\ Porto Alegre)
}

Jarosław Sułkowski

Autor jest stypendystą w ramach projektu „Kształcenie kadr na potrzeby rynku flexicurity i gospodarki opartej na wiedzy - oferta kierunków nauk humanistyczno-społecznych UŁ”, wspótfinansowanego ze środków Unii Europejskiej w ramach Europejskiego Funduszu Społecznego. Dr w Katedrze Prawa Konstytucyjnego Uniwersytetu Łódzkiego http://dx.doi.org/10.18778/8088-114-3.20

\section{Wprowadzenie}

Przedmiotem artykułu jest analiza znanego na całym świecie eksperymentu polityczno-ekonomicznego zastosowanego po raz pierwszy w Porto Alegre - budżetu partycypacyjnego ${ }^{1}$. Budżet ten był planem finansowym miasta kilkanaście lat (ostatni raz obowiązywał w 2004 r.). Doprowadził do znacznego jego przeobrażenia, w tym do rozwoju

1 Problematyka budżetu partycypacyjnego stała się przedmiotem szerokiej dyskusji - zob. m.in. L. Avritzer, Sociedad civil, espacio público y poder local. Un análisis del presupuesto participativo en Belo Horizonte y Porto Alegre, [w:] Sociedad civil, esfera pública y democratización en América Latina: Brasil, red. E. Dagnino, Mexico 2002; L. Avritzer, Democracy and the public space in Latin America. Princeton 2002; L. Avritzer, Models of democratic deliberation: participatory budgeting in Brazil, [w: ] Democratizing democracy: beyond the liberal democratic canon, red. B. de Sousa Santos, New York 2006; L. Avritzer, Participatory Institutions in Democratic Brazil, Baltimore 2009. G. Baiocchi, Militants and citizens: the politics of participation in Porto Alegre, Stanford 2005; B. Wampler, Orçamento Participativo: uma explicação para as amplas variaçoes nos resultados, [w:] A inovação democratica no brasil, red. L. Avritzer, Z. Navarro, São Paulo. B. Wampler, L. Avritzer, The Spread of Participatory Budgeting in Brazil: From Radical Democracy to Participatory Good Government, "Journal Of Latin American Urban Studies”, New York, vol. 7, Fall, p. 37-52; B. Wampler, Participatory Budgeting in Brazil: contestation, cooperation, and accountability, Pennsylvania State University Press 2008; E. Aaragones, S. Sanches-Pages, A theory of participatory democracy based on the real case of Porto Alegre, „European Economic Review” 2008, A. Marquetti, C. E. Schonerwald de Silva, Al. Campbell, Participatory Economic Democracy in Action. Participatory Budgeting in Porto Alegre, 1989-2004, 2009, http://content.csbs.utah. edu/ al/articles/Sub_PB1.pdf (dostęp 1.06.2015). 
infrastrukturalnego. Nie ulega wątpliwości, że miasto wiele zyskało dzięki zastosowaniu tej nowej metody zarządzania, partycypacji obywatelskiej oraz redystrybucji środków finansowych. Budżet przyczynił się także do rozwoju odpowiedzialnej i przyjaznej obywatelom administracji lokalnej.

Pytanie o możliwość wykorzystania budżetu partycypacyjnego $\mathrm{w}$ innych państwach tylko prima facie jest retoryczne. Na przykładzie polskich doświadczeń można stwierdzić, że bez zrozumienia mechanizmów warunkujących prawidłowe funkcjonowanie budżetu partycypacyjnego (np. przyjęcia odpowiedniego poziomu finansowania lokalnego), osiągnięcie jego celów może okazać się trudne.

Artykuł ma na celu przedstawienie budżetu partycypacyjnego Porto Alegre jako instrumentu demokracji uczestniczącej. W tym kontekście ciekawa jest geneza oraz uwarunkowania jego wprowadzenia. Dzięki zaprezentowaniu cech tej instytucji możliwe stanie się zidentyfikowanie niezbędnych warunków wprowadzenia takiego mechanizmu w danej społeczności lokalnej.

\section{Geneza budżetu partycypacyjnego}

Budżet partycypacyjny jest instytucją nową w Polsce i z nieco dłuższą historią w Europie. Można jednak przyjąć, że znajduje się w fazie rozwoju i wciąż jeszcze opiera się głównie na obywatelskiej spontaniczności², co niesie za sobą pewne zagrożenia (wykorzystywanie w rozgrywkach politycznych). Populacja objęta budżetami partycypacyjnymi w 2009 r. sięgnęła ponad 8000000 ludzi i wartość ta stale rośnie.

Zainteresowanie budżetem partycypacyjnym jest wynikiem licznych procesów społecznych i politycznych. Należy je postrzegać w szerszej perspektywie - jako skutek globalizacji oraz w perspektywie węższej jako dowód zainteresowania obywateli polityką lokalną i jako pochodną zniechęcenia polityką ogólnokrajową.

Geneza budżetu partycypacyjnego (co dobitnie potwierdza przykład Porto Alegre) ma tło polityczne i ustrojowe i wiąże się z kryzysem form

2 Dlatego polska regulacja prawna budżetów partycypacyjnych jest w zasadzie punktowa. Jest jednak zbyt wcześnie, by formułować jednoznaczne wnioski o konieczności jej rozbudowania. Konieczne jest monitorowanie zasad funkcjonowanie budżetu partycypacyjnego pod kątem konieczności wprowadzenia określonych mechanizmów prawnych. 
demokracji pośredniej. W Porto Alegre włączenie obywateli w decydowanie o polityce miejskiej było wynikiem wygranej w wyborach lokalnych przez Partię Pracy, której zwycięstwo wyborcze było pośrednim skutkiem wieloletniej dyktatury. Partia Pracy obiecała bowiem, że po dojściu do władzy w mieście (tłumiony wcześniej) głos decydowania o sprawach lokalnych, w tym o budżecie miejskim, odda członkom społeczności lokalnej. Popularność budżetu partycypacyjnego nie musi jednak wiązać się z aż tak ewidentną dysfunkcją państwa i władzy publicznej. Wystarczy, jak pokazują doświadczenia polskie, dominacja parlamentu z przedstawicielami niewłaściwie rozumiejącymi swoją rolę i zawłaszczanie przestrzeni lokalnej przez centralnie kierowane partie polityczne. Partie polityczne jako stałe organizacje zrzeszające obywateli i posiadające program, zdolne do podejmowania decyzji mających na celu rozwiązywanie problemów społecznych, nie powinny ograniczać się do formowania programów, gdyż konieczne jest także wcielanie ich w życie. Jako podmioty uczestniczące $\mathrm{w}$ swobodnym współzawodnictwie politycznym partie mają obowiązek przedstawiać konkurencyjne rozwiązania i strategie oraz pełnić rolę ośrodków debat i dyskusji publicznych (swoistych think-tanków) dotyczących reform politycznych, społecznych i gospodarczych. Niestety oczekiwanie to nie zostaje spełnione, co wzmaga u obywateli poczucie nieprzydatności klasy politycznej i typowych form demokracji pośredniej.

Okolicznością sprzyjającą wzrostowi zainteresowana budżetem partycypacyjnym jest także brak czasowości polityki i dominacja w niej celów krótkoterminowych, a nawet jednorazowych. Procedowanie sprawami publicznymi jest sekwencyjne i jednowątkowe z niewielkim udziałem nie-polityków. Tymczasem stymulacja, zarządzanie lub reformowanie spraw publicznych powinno być procesem ciągłym, wielowątkowym i wielościeżkowym, wymaga zaangażowania szerokiego kręgu podmiotów. Istotny jest udział polityków, członków społeczności oraz tzw. trzeciego sektora.

Istotne znaczenie dla genezy budżetu partycypacyjnego ma zachodząca globalizacja polityki i prawa. Globalizacja, choć nie jest zjawiskiem nowym, wciąż nie została jednoznacznie zdefiniowana. Nie można jednak się temu dziwić, stanowi ona bowiem złożony i niepoddający się jednej logice proces „intensyfikacji ogólnoświatowych reakcji społecznych, które wiążą oddalone od siebie miejsca w taki sposób, że lokalne wydarzenia są kształtowane przez wydarzenia występujące w innych oddalonych o wiele mil miejscach i vice versa".

3 A. Giddens, Runaway World. How Globalization Is Reshaping our Lives, New York, 2000, cyt. za: R. Zenderowski, Czy globalizacja unieważni nacjonalizmy i tożsamości narodowe?, „Studia Bobolanum” 2011, nr 1, s. 140. 
Brak definicji globalizacji zastępowany jest próbami opisania tego zjawiska. $\mathrm{Z}$ uwagi na ograniczone ramy opracowania nie ma potrzeby przytaczania wszystkich cech globalizacji, niemniej jednak należy zwrócić uwagę na trzy najważniejsze kwestie.

Po pierwsze, globalizacja ściśle wiąże się z rewolucją informacyjną, rozwojem technologii informatycznych i wywołanymi przez nie zmianami w zakresie przetwarzania i przekazywania informacji oraz zarządzania nimi ${ }^{4}$. Budżet partycypacyjny jest oparty na nowoczesnych formach przetwarzania informacji.

Po drugie, ma ona charakter wieloaspektowy. Przede wszystkim jest zjawiskiem finansowym, wiążącym liczne instytucje bankowe, ubezpieczeniowe i inne finansowe poszczególnych państw w całość (włącznie z Bankiem Światowym oraz Międzynarodowym Funduszem Walutowym - uzależnionymi od Stanów Zjednoczonych) $)^{5}$. Globalizacja ma także silny wymiar gospodarczy oparty na światowym rynku kapitału, dóbr i usług. Globalizacja jest także - co oczywiste - zjawiskiem politycznym i militarnym. Nadto, ma ona wymiar kulturowy - wraz z przepływem dóbr, usług i informacji w świecie upowszechniają się bowiem wzorce (wartości) powstałe w jednym kręgu cywilizacyjnym, które wypierają elementy lokalne ${ }^{6}$.

Wreszcie należy zwrócić uwagę, że globalizacja jest zjawiskiem dynamicznym i dalekosiężnym w skutkach, jednak w historii państwowości nie nowym. Obecnie jesteśmy świadkami trzeciej fali globalizacji. Obserwując skutki dwóch jej wcześniejszych etapów - wielkich odkryć geograficznych oraz rewolucji przemysłowej, należy przyjąć, że skutki globalizacji XXI w. będą znaczące.

Budżet partycypacyjny jest także pośrednim efektem rozwoju techniki, Internetu i nowych metod decydowania o sprawach publicznych (e-demokracji), takich jak e-voting, NIMBY (Not In My Back Yard - „nie na moim podwórku”), YMIBY (Yes, In My Back Yard - „tak, na moim podwórku"), BANANA (build absolutely nothing anywhere near anything) czy coraz popularniejszej, także w Polsce, procedury odwoławczej re-call, czy też nowej regulacji prawa do petycji ${ }^{7}$. Obecnie można mówić o zarysowywaniu się tendencji szerszego wykorzystywania mechanizmów, za pomocą których obywatele zabierają głos w sprawach publicznych.

4 R. Piotrowski, Globalizacja i konstytucja, „Zagadnienia Sądownictwa Konstytucyjnego" 2012, t. 2, s 14.

5 W. Szostak, Globalizacja a suwerenność państwa wspótczesnego, [w:] Nowoczesny Lewiatan. Studia nad współczesnym państwem, red. J. Kornaś, Kielce 2006, s. 13-14.

6 Ibidem, s. 14.

7 Zgodnie z art. 63 Konstytucji realizacje tego prawa podmiotowego może nastąpić przez złożenie wniosku, skargi lub petycji. Artykuł 63 Konstytucji nie ogranicza formy dokumentu, jaki może być złożony przez jednostkę. Posłużenie się przez prawodawcę trzema jego rodzajami należy interpretować w taki sposób, by zapewnić 


\section{Definicja budżetu partycypacyjnego i jego modele}

Cechą charakterystyczną definicji budżetu partycypacyjnego są liczne problemy w jej sformułowaniu. Wypracowanie tej definicji nastręcza poważnych trudności, zwłaszcza gdy weźmie się pod uwagę odmienności $\mathrm{w}$ funkcjonowaniu budżetów partycypacyjnych w różnych państwach. W najogólniejszym ujęciu budżet partycypacyjny polega na udziale niereprezentantów (podmiotów niewybieralnych) w alokacji środków budżetowych. Należy przy tym wyróżnić trzy elementy, które są differentia specifica tego budżetu.

Po pierwsze, musi on być instytucją przynależną do demokracji deliberacyjnej. Omawiany budżet należy postrzegać jako publiczny proces komunikacji zorientowany na poszukiwanie odpowiednich argumentów przemawiających za określonymi ocenami i rozwiązaniami omawianych projektów. Chodzi więc o powrót do debaty i dialogu jako centralnego elementu demokracji, gdyż deliberacja jest dyskusją dążącą do wypracowania konsensusu8.

Po drugie, budżet musi być instytucją legitymizującą lokalne cele polityczne i przez to samą władzę lokalną. Legitymizacja ta jest wielowymiarowa, budżet $\mathrm{z}$ jednej strony pozwala zorientować się $\mathrm{w}$ realiach budżetowych, $\mathrm{z}$ drugiej - w potrzebach mieszkańców, a przez wybór celów wzmacnia identyfikację ze wspólnotą lokalną i rozwija postawy społeczeństwa obywatelskiego. Trzecim elementem wyróżniającym jest zapewnienie kontroli społecznej przez zwiększenie przejrzystości finansowania i funkcjonowania administracji. Celowi temu służy powtarzalność projektowania - łączenie przeszłości (the record of the past) i przyszłości, gdyż daje ono obraz, na co środki były przekazane, a jakie cele

jednostkom możliwość kierowania do władz publicznych wszelkich postulatów, żądań i próśb, byle tylko dotyczyły one zadań publicznych i pod warunkiem, że będą konkluzywne i postulatywne. Minimalnym wymogiem petycji jest więc odniesienie się do zadania publicznego realizowanego przez władze publiczne lub podmioty, którym zlecono wykonywanie takich zadań, opis stanu faktycznego oraz wniosek o podjęcie określonych działań. Oczywiście z punktu widzenia semantyki istnieją różnice między skargą, petycją i wnioskiem. Skarga będzie najczęściej odnosić się do stanów przesztych, a wniosek do przyszłych i mimo że skarga co do zasady jest pismem indywidulanym, a petycja zbiorowym, to jednak ani nazwa, ani zatytułowanie określonego pisma przez wnoszącego petycję nie ma znaczenia. Formalizm powinien być tu zredukowany do minimum. Obowiązkiem adresatów petycji jest wydobycie z jej treści opisanego problemu i działanie w myśl zasady in dubio pro libertate. Tylko przekonujące argumenty mogą uzasadniać zignorowanie wniosku, petycji lub skargi.

8 B. Jabłońska, W stronę demokracji deliberacyjnej? O politycznym komunikowaniu na tematy europejskie w polskiej prasie, s. 123. 
nie były nim objęte, a ponadto wprowadza element weryfikacji celowości i skuteczności finansowania określonych inwestycji.

W literaturze poświęconej społecznej partycypacji jedną z ważniejszych kwalifikacji modeli budżetów obywatelskich jest podział zaproponowany przez Y. Sintomer, C. Herzberg, A. Röcke ${ }^{9}$. Wyróżnili oni sześć modeli budżetu partycypacyjnego: model Porto Alegre w wersji europejskiej (Hiszpania, Włochy), model partycypacji sąsiedzkiej (proximity participation), model konsultacji, model partycypacji wspólnoty lokalnej i model partycypacji inicjatyw wielostronnych (multi-stakeholder participation).

Pierwszy z modeli, silnie nawiązujący do Porto Alegre (PA), opiera się na włączeniu w proces decyzyjny wybranych przez wspólnotę członków społeczności lokalnej na otwartych spotkaniach. Członkowie wspólnoty wybierają także rady, które ustalają cele wydatkowania na nadchodzący rok. Następnie odbywają się spotkania na wyższych poziomach (dystryktu, miasta) z udziałem lokalnych polityków, przedstawicieli stowarzyszeń, organizacji. W modelu tym istnieje dwuetapowość. Najpierw dochodzi do wyłonienia propozycji konkretnych projektów na poziomie niższym i ich przegłosowania przez zgromadzenie członków wspólnoty. Następnie przedstawiciele władz lokalnych oceniają projekty, a końcowa ich wersja trafia do rady miejskiej, która włącza listę do budżetu miasta. Po uchwaleniu budżetu ustanawia się podmiot monitorujący sposób wykonania projektowanych inwestycji (składający się z przedstawicieli obu poziomów). W modelu tym istnieje daleko posunięty formalizm, a radni mają obowiązek uwzględnić propozycje mieszkańców

Model partycypacji sąsiedzkiej (proximity participation) ma charakter wyłącznie konsultacyjny (PS). Opiera się na „selective listening”, który polega na tym, że radni wcielają tylko te projekty zgłoszone uprzednio przez członków wspólnoty, które odpowiadają zdefiniowanym przez nich celom i interesom. Konsultacje z członkami wspólnoty odbywają się za pośrednictwem różnych mediów, także Internetu. Na poziomie lokalnym ustalane są cele strategiczne, a decyzje zapadają w drodze konsensusu. Konsultacje prowadzi samorząd, ich stroną są radni i z tego względu można oczekiwać realizacji ustaleń dokonanych na etapie konsultacji.

Kolejny rodzaj budżetu partycypacyjnego ma także charakter wyłącznie konsultacyjny (K). Przedmiotem dyskusji jest polityka finansowa i jej transparentność. Samorząd przedstawia informacje na jej temat, a następnie ocenia się tę politykę na spotkaniach przedstawicieli członków wspólnoty wybieranych losowo. Są one otwarte dla pozostałych członków wspólnoty.

9 Y. Sintomer, C. Herzberg, A. Röcke, Participatory Budgeting in Europe: Potentials and Challenges, „International Journal of Urban and Regional Research” 2008, vol. 321, s. 169. 
Ocena polityki finansowej odbywa się albo zadaniowo (basen, biblioteka itp.) albo z punktu widzenia równowagi budżetowej. W trakcie spotkania uczestnicy mogą zadawać pytania i zgłaszać własne propozycje.

W dwóch kolejnych modelach - partycypacji wspólnoty (PW) lokalnej oraz partycypacji inicjatyw wielostronnych (PIW) - środki na finansowanie określonych celów tylko częściowo pochodzą z budżetów lokalnych, gdyż cele są wspólfinansowane przez NGO-sy, podmioty prywatne czy nawet za pośrednictwem programów narodowych. Budżety odnoszą się więc do funduszy na cele inwestycyjne, kulturalne, środowiskowe lub społeczne. Decyzje dotyczące budżetu podejmowane są przez komitet składający się z przedstawicieli samorządu i podmiotów współfinansujących. Różnica między tymi modelami sprowadza się do współfinansowania sektora prywatnego, które w modelu partycypacji wspólnoty lokalnej nie występuje, podczas gdy w modelu partycypacji inicjatyw wielostronnych (multi-stakeholder participation) prywatni sponsorzy mają wpływ na alokację środków (choć większa część środków musi pochodzić z budżetu lokalnego).

\begin{tabular}{|l|l|l|l|l|l|}
\cline { 2 - 6 } \multicolumn{1}{c|}{} & \multicolumn{1}{c|}{ PA } & \multicolumn{1}{c|}{ PS } & \multicolumn{1}{c|}{ K } & \multicolumn{1}{c|}{ PW } & \multicolumn{1}{c|}{ PIW } \\
\hline $\begin{array}{l}\text { Kto podejmuje } \\
\text { decyzję }\end{array}$ & $\begin{array}{l}\text { Rada delega- } \\
\text { tów wspólnoty }\end{array}$ & Samorząd & Samorząd & Komitet & Komitet \\
\hline $\begin{array}{l}\text { Przedmiot } \\
\text { dyskusji }\end{array}$ & $\begin{array}{l}\text { Inwestycje } \\
\text { publiczne }\end{array}$ & $\begin{array}{l}\text { Cele strate- } \\
\text { giczne danej } \\
\text { wspólnoty }\end{array}$ & $\begin{array}{l}\text { Budżet jako } \\
\text { całość albo } \\
\text { jego poszcze- } \\
\text { gólne zadania }\end{array}$ & $\begin{array}{l}\text { Konkretne } \\
\text { projekty } \\
\text { wspólnoty }\end{array}$ & $\begin{array}{l}\text { Konkretne } \\
\text { projekty }\end{array}$ \\
\hline Skutek & $\begin{array}{l}\text { Wiążąca de- } \\
\text { cyzja }\end{array}$ & Konsultacja & Konsultacja & $\begin{array}{l}\text { Partnerstwo } \\
\text { publiczno- } \\
\text {-prywatne }\end{array}$ & $\begin{array}{l}\text { Partnerstwo } \\
\text { publiczno- } \\
\text {-prywatne }\end{array}$ \\
\hline Kontrola & $\begin{array}{l}\text { Rada delega- } \\
\text { tów }\end{array}$ & Samorząd & Samorząd & $\begin{array}{l}\text { Samorząd } \\
\text { i sponsorzy }\end{array}$ & $\begin{array}{l}\text { Samorząd } \\
\text { i sponsorzy }\end{array}$ \\
\hline
\end{tabular}

Rysunek 1. Decydenci w poszczególnych modelach budżetu partycypacyjnego

Wyróżnione modele są pośrednim dowodem na duże zróżnicowanie budżetów partycypacyjnych, potwierdza je także Raport Rady Europy z 2011 r. na temat roli samorządów lokalnych w ustalaniu budżetów partycypacyjnych ${ }^{10}$. Dokument przedstawia wyniki badań przeprowadzonych w 25 państwach. Ukazuje on liczne odmienności w poszczególnych krajach. Różnice te są widoczne w regulacji prawnej budżetu. Istnieje ona tylko w 9 państwach

10 N. Vodusek, A. Biefnot, Report on the CDLR survey of the role of central/regional government in participatory budgeting at local level.

Legal framework and current practice in member states, https://wcd.coe.int/com. instranet.InstraServlet?command=com .instranet.CmdBlobGet\&InstranetImage$=2567401 \&$ SecMode $=1 \&$ Docld $=1801348 \&$ Usage $=2$ (dostęp 1.06.2015 r.). 
- przede wszystkim w ustawach o finansach publicznych oraz w aktach prawnych dotyczących uchwalania budżetów lokalnych. W niektórych państwach (Bułgaria, Grecja, Słowenia) samorządy lokalne mają obowiązek wykorzystywania mechanizmów partycypacyjnych w tworzeniu budżetów, w innych państwach (np. Malta, Finlandia) zachęca się samorządy do korzystania $\mathrm{z}$ tych mechanizmów. Według raportu $\mathrm{w}$ większości państw stosuje się następujące formy włączenia obywateli w uchwalanie budżetu: a) ewentualne przesłanie projektu budżetu członkom społeczności albo innym podmiotom (Austria, Niemcy); b) opublikowanie projektu budżetu w internecie (Chorwacja, Dania, Estonia, Słowacja), niekiedy w wersji uproszczonej; c) zorganizowanie wysłuchania publicznego, paneli, ankiet budżetowych (Portugalia, Turcja); d) zgłaszanie uwag, wniosków do samorządów dotyczących budżetów z reguły w terminie 10-14 dni; e) możliwość zgłaszania postulatów i wniosków online (Niemcy, Dania, Wielka Brytania).

Interesująco przedstawia się zagadnienie zakresu związania samorządów opiniami członków wspólnoty. W większości państw opinie o projekcie budżetu nie są wiążące - samorządy mają swobodę $\mathrm{w}$ akceptowaniu propozycji członków wspólnoty, natomiast w niektórych państwach wymaga się uzasadnienia nieuwzględnienia propozycji członków wspólnoty ${ }^{11}$.

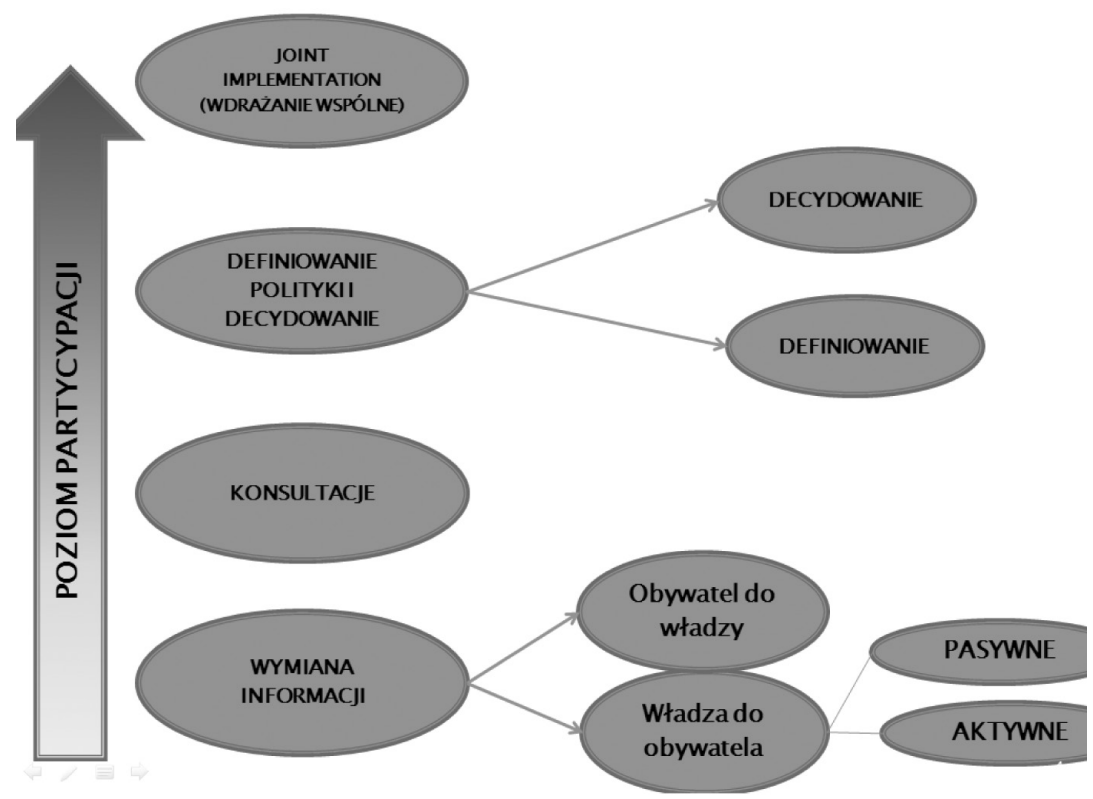

Rysunek 2. Typy i poziomy bezpośredniej partycypacji obywateli ${ }^{12}$

11 Ibidem.

12 Opracowanie na podstawie I. Koryanov, T.D. Sisk, Participatory democracy, [w:] Democracy At The Local Level, A Guide for the South Caucasus, 2003, http://iknowpolitics. org/ sites/default/files/democracy-locallevel-southcaucus. pdf (dostęp 2.06.2015 r.), s. 26. 


\section{Budżet partycypacyjny jako przykład instrumentu demokracji uczestniczącej}

Demokracja uczestnicząca opiera się na kolektywnym działaniu członków wspólnoty i prowadzi do podjęcia określonych decyzji. Uproszczeniem byłoby jednak uznanie, że zakłada ona wyłączność form demokracji bezpośredniej, gdyż udział członków wspólnoty łączy się z elementami demokracji przedstawicielskiej. Istnieją liczne mechanizmy demokracji uczestniczącej, ich klasyfikacja może zależeć od stopnia aktywności (partycypacji) obywatelskiej (zob. rys. 2).

Pierwszy rodzaj sposobów partycypacji zakłada niewielki udział obywateli, a jego istota sprowadza się do wymiany informacji między władzą lokalną a członkami wspólnoty. Dane te mogą być przekazywane obywatelom, którzy są adresatami kierowanych do nich informacji. Rola obywateli może być przy tym pasywna, gdy adresaci zapoznają się z danymi (np. z udostępnionych zbiorów, tablic ogłoszeń, biuletynów informacji publicznej) lub aktywna, gdy wcześniej sami podejmują działania mające na celu pozyskanie udostępnionych przez władze lokalne informacji. Przepływ informacji może też następować w odwrotnym kierunku - członkowie wspólnoty sami dostarczają władzom lokalnym określone informacje (wnioski, skargi, petycje). W tym ostatnim przypadku poziom aktywności jest wyższy i wiąże się z wolą obywatela przekazania określonych informacji.

Druga grupa sposobów partycypacji wykracza poza zaznaczony dotąd wymiar informacyjny (opiniotwórczy). Należą do niej konsultacje (także opiniotwórcze), które różnią się od informowania systematycznością i powtarzalnością, koncentrują się częściej na sprawach lokalnych, a nie indywidualnych, zawierają w sobie element decydowania rozumiany jako oczekiwanie od decydentów ustosunkowania się do zgłaszanych w toku konsultacji próśb czy postulatów.

Trzeci rodzaj uczestniczenia w sprawach lokalnych to definiowanie polityki i decydowanie. Zakłada się współdziałanie władz lokalnych i członków społeczności na obu etapach (definiowania i decydowania). Platformą porozumienia stają się ciała wspólne składające się z podmiotów definiujące cele społeczne (zebrania miejskie) oraz podmioty realizujące te cele (władza lokalna). W tym miejscu zasadniczo sytuuje się budżet partycypacyjny w Porto Alegre. Czwarta kategoria działań uczestniczących to wdrażanie wspólne (joint implementation). Cechą istotną odróżniającą od poprzedniego rodzaju działania jest pomoc korporacyjna (substratu ludzkiego) i fundacyjna (majątku prywatnego) w planowaniu i realizacji inwestycji. Spektrum podmiotowe realizowanych działań jest szerokie, zalicza się do niego trzeci sektor, NGO-sy oraz biznes prywatny. 
Budżet uchwalany w brazylijskim Porto Alegre był aktem, w przygotowanie którego zaangażowanych było wiele podmiotów ${ }^{13}$. Na poziomie lokalnym, w każdej dzielnicy, funkcjonowało zgromadzenie dzielnicowe, a niezależnie od nich - w każdym $\mathbf{z}$ pięciu obszarów tematycznych - zgromadzenie tematyczne. W obu zgromadzeniach mogli brać udział mieszkańcy miasta, którzy ukończyli 16 rok życia. W trakcie spotkań dzielnicowych prowadzono akcję edukacyjną i przygotowywano spotkania tematyczne (kwestie ogólnomiejskie) oraz hierarchizowano priorytety miejskie (ustalając gradację celów, np. w obszarach gospodarki ściekowej, śmieciowej, budowy dróg i chodników, pomocy społecznej, zdrowia, edukacji, transportu itp.). Oprócz zgromadzeń dzielnicowych mieszkańców odbywały się zgromadzenia ogólnomiejskie tematyczne: oświaty, kultury, czasu wolnego; zdrowia i opieki społecznej; rozwoju gospodarczego i finansowego miasta; komunikacji miejskiej i ruchu ulicznego oraz organizacji i planowania rozwoju miasta oraz ochrony środowiska. Były to ciała dyskusyjne (skategoryzowane merytorycznie) omawiające projekty konsultowane wcześniej przez zgromadzenia dzielnicowe.

Podmiotem odgrywającym dużą rolę w opracowaniu budżetu było także forum delegatów. Można było wyróżnić forum regionalne i tematyczne. Forum było ciałem przedstawicielskim zebrań danej dzielnicy zgodnie z regułą: im liczniejsze zebranie, tym więcej delegatów z danej dzielnicy ${ }^{14}$ (1:5, od 1996 1:20). W skład forum nie wchodzili ani radni miejscy ani urzędnicy. Funkcja członka forum była kadencyjna (jednoroczna). Spotkania forum odbywały się raz w miesiącu (z otwartym dostępem mieszkańców). Forum było platformą konsultacyjną z mieszkańcami. W toku jego prac powstawały właściwe propozycje inwestycyjne.

Istotne znaczenie w opracowaniu budżetu miała także Rada Budżetu Partycypacyjnego składająca się z działających społecznie radnych, wybieranych przez poszczególne zgromadzenia ${ }^{15}$. Możliwość zasiadania w Radzie została ograniczona czasowo (jednoroczna kadencja) oraz liczebnie (ponowny wybór był dopuszczalny tylko raz). Co istotne, zgromadzenie w trybie nadzwyczajnym mogło odwołać członka (radnego).

Budżet partycypacyjny w Porto Alegre opierał się na jednorocznych cyklach zgromadzeń i spotkań, które odbywały na dwóch poziomach:

13 R. Abers, Porto Alegre and the Participatory Budget. Civic Education, Politics And The Possibilities For Replication, http://fimforum.org/en/library/Porto_Alegre_and_ the_Participatory_Budget.pdf (dostęp 4.06.2015 r.), s. 84-88.

14 Licznik reprezentatywności wynosit początkowo 1 członka forum na każdych 5 delegatów, a następnie proporcję tę zmieniono na 1:20.

15 D. Chavez Miños, Porto Alegre, Brazil: A new, sustainable and replicable model of participatory and democratic governance?, http://ibrarian.net/navon/paper/Daniel_ Chavez_Mi_os.pdf ?paperid=5644680 (dostęp 4.06.2015 r.), s. 11. 
terytorialnym (dotyczącym 16 osiedli miasta) i tematycznym (dotyczącym poszczególnych aspektów rozwoju miasta podzielonych na 5 obszarów) ${ }^{16}$. Pojedynczy cykl składał się z trzech etapów. Pierwszy etap (marzec-kwiecień) rozpoczynały otwarte zgromadzenia w 16 osiedlach i w 5 obszarach tematycznych. Ich celem było udzielenie mieszkańcom podstawowych informacji dotyczących budżetu partycypacyjnego, jak również pozyskanie nowych uczestników - spotkaniom towarzyszyła szeroko zakrojona kampania informacyjna. Na zgromadzeniach mieszkańcy uzyskiwali informacje dotyczące inwestycji zrealizowanych w poprzednim roku oraz projektów proponowanych do realizacji przez przedstawicieli Urzędu Miasta w nowym roku, a także dokonywali rewizji zasad przeprowadzenia budżetu partycypacyjnego. Co ważne, mieszkańcy wspólnie określali priorytety inwestycyjne miasta - choć co roku ulegały one zmianom; wiele zagadnień, takich jak: polityka mieszkaniowa, edukacja, infrastruktura drogowa czy kanalizacja, regularnie wybierano jako najważniejsze ${ }^{17}$.

Pod koniec serii zgromadzeń mieszkańcy głosowali na delegatów reprezentujących poszczególne osiedla na forach tematycznych i terytorialnych. Delegaci musieli uzyskać nie większość głosów, ale poparcie określonej liczby mieszkańców, których odtąd bezpośrednio reprezentowali na forach (liczba głosów koniecznych do uzyskania poparcia systematycznie się zwiększała wraz ze wzrostem uczestnictwa mieszkańców $\mathrm{w}$ budżecie partycypacyjnym).

Fora odbywały się raz na miesiąc, by dalej mobilizować mieszkańców do uczestnictwa, monitorować proces przeprowadzania budżetu partycypacyjnego w danym roku, a także prowadzić dialog dotyczący poszczególnych jednostek terytorialnych, określonych kwestii tematycznych reprezentowanych przez poszczególne fora, radą budżetu partycypacyjnego a przedstawicielami Urzędu Miasta. Bezpośrednio po wyborze delegaci uczestniczyli w kilkudniowych warsztatach dotyczących zarządzania miastem (w szczególności jego budżetem), zdobywając wiedzę i umiejętności potrzebne w ich dalszej działalności. Delegaci byli wybierani na roczną kadencję, teoretycznie bez możliwości reelekcji; nie otrzymywali żadnego wynagrodzenia i podlegali ścisłej kontroli mieszkańców, którzy ich poparli; mogli być w każdej chwili odwołani. W praktyce oznaczało to, że mieszkańcy, którzy nie mieli możliwości lub chęci angażowania się w dalsze dyskusje nad budżetem miejskim mieli pewność, że wybrany przez nich delegat będzie reprezentował potrzeby ich osiedla ${ }^{18}$.

16 Opis budżetu przytaczam za W. Kłębowskim, Budżet partycypacyjny krótka instrukcja obsługi, http://www.instytutobywatelski.pl (dostęp 4.06.2015 r.), s. 26-29.

17 Ibidem.

18 Ibidem. 
Podczas drugiego etapu (kwiecień-maj) odbywały się tzw. spotkania pośrednie - na poziomie terytorialnym delegaci rozmawiali z mieszkańcami o potrzebach poszczególnych osiedli lub mniejszych obszarów (poszczególnych ulic czy podwórek), podczas gdy na poziomie tematycznym dyskutowano o projektach ogólnomiejskich. To na spotkaniach pośrednich powstawały właściwe propozycje inwestycyjne, które były jednocześnie hierarchizowane według trzech kryteriów: priorytety inwestycyjne ustalone przez mieszkańców na etapie pierwszym; współczynnik „jakości życia" w dzielnicy, której dotyczyła dana inwestycja (jakość i dostępność poszczególnych usług i elementów infrastruktury); liczba mieszkańców. Tym samym środki trafiały do najbardziej potrzebujących obszarów miasta i grup społecznych. Spotkania pośrednie trwały około dwóch godzin i cieszyły się ogromną frekwencją (zwłaszcza osób niezamożnych i kobiet) - to tutaj miały miejsce najgorętsze dyskusje i nierzadko dochodziło do konfliktów pomiędzy uczestnikami. Wszystkie spotkania i fora w ramach budżetu partycypacyjnego były w pełni otwarte. Żaden $\mathrm{z}$,uczestników” procesu - niezależnie od funkcji sprawowanych poza budżetem partycypacyjnym - nie był w żaden sposób uprzywilejowany ${ }^{19}$.

W dyskusjach uczestniczyli eksperci z Urzędu Miasta, odbywały się też wizyty w miejscach potencjalnych inwestycji, pozwalające delegatom i mieszkańcom naocznie ocenić potrzeby poszczególnych obszarów miasta.

W trzecim etapie (maj-lipiec) ponownie zawiązywały się otwarte zgromadzenia - tym razem, by wybrać członków Rady Budżetu Partycypacyjnego z każdego zgromadzenia terytorialnego i tematycznego. Członkowie Rady mogli być wybrani tylko dwa razy i - podobnie jak delegaci - byli ściśle kontrolowani przez mieszkańców i nie otrzymywali wynagrodzenia. Rada miała za zadanie zebrać zhierarchizowane propozycje z całego miasta i porównać ich listę z dostępnymi środkami (na których ilość Rada miała wpływ, współdecydując o lokalnej polityce podatkowej) oraz istniejącymi regulacjami formalno-prawnymi. Efektem jej pracy był projekt budżetu miejskiego - od października do grudnia kolejno przedyskutowany z mieszkańcami na spotkaniach w dzielnicach, a następnie przekazany administracji i przekształcony przez Radę w plan inwestycyjny, którego wdrożenie było monitorowane przez mieszkańców ${ }^{20}$.

Budżet partycypacyjny w wersji obowiązującej w Porto Alegre cechował się daleko posuniętą deliberatywnością ${ }^{21}$. Istotne jest, że na

19 Ibidem.

20 Ibidem.

21 Początki były jednak trudne - w pracach nad budżetem udział członków społeczności był bardzo skromny - zob. K. Koonings, Strengthening citizenship in Brazil's democracy. Local participatory governance in Porto Alegre, „Bulletin of Latin America Research" 2004, vol. 23, http://www.chs. ubc.ca/participatory/docs/Koonings\%28A\%29.pdf (dostęp 4.06.2015 r.), s. 91-92. 
każdym etapie jego opracowywania obecni byli mieszkańcy oraz przedstawiciele władz lokalnych. Tak aktywny i wielowątkowy udział członków społeczności był ściśle powiązany z genezą tej instytucji. Budżet stał się bowiem remedium na zaniedbania wywołane okresem rządów junty wojskowej (1964-1985)22. Po długim okresie wybory wygrała Partia Pracujących, która w pierwszych latach swoich rządów starała się wprowadzić mechanizmy zapewniające obywatelom bezpośredni udział w procesie decyzyjnym, a tym samym wzmocnić swoją legitymizację w obliczu trudnych decyzji podejmowanych w warunkach nowo odzyskanej demokracji ${ }^{23}$.

Cechą budżetu była także daleko posunięta instytucjonalizacja ${ }^{24}$. Była on widoczna na etapie planowania budżetu - przyjęcie jego założeń wstępnych (zmiennych ekonomicznych, demograficznych, infrastrukturalnych), projektowania - podział merytoryczny zebrań i forum - aż po etap realizacji i monitorowania. Co istotniejsze, za organizację posiedzeń wspólnot sąsiedzkich oraz zebrań delegatów, jak również za zapewnienie podstawowego zaplecza technicznego odpowiedzialne były organy władzy lokalnej. Członkowie tej władzy brali też udział w procesie projektowania budżetu. Stały kontakt władzy lokalnej z mieszkańcami był więc gwarancją, że plany budżetowe zostaną zrealizowane.

\section{Budżet Porto Alegre a doświadczenia polskie}

Rozwiązania polskie są trudne do zsumowania, gdyż procedury przygotowania budżetów partycypacyjnych w poszczególnych miastach różnią się. Doświadczenia Porto Alegre pozwalają jednak określić kilka warunków, których spełnienie jest niezbędne do nadania polskim budżetom obywatelskim charakteru partycypacyjnego.

$22 \mathrm{H}$. Cleuren, Administrating participatory budgeting in Porto Alegre. Street level officials and organisational preconditions, „Estado, Gobierno, Gestión Publica, Revista Chilena de Administración Publica" 2008, No. 12 Diciemnre 2008, http://www.dialnet. unirioja.es/descarga/articulo/2932574.pdf (dostęp 5.06.2015 r.), s. 25-26.

23 A. Rytel-Warzocha, Partycypacja społeczne w sprawach budżetowych. Model Porto Alegre jako pierwowzór rozwiq̨zań europejskich, „Przegląd Prawa Konstytucyjnego" 2007, nr 1, s. 97.

24 A. Novy, B. Leubolt, Participatory Budgeting in Porto Alegre: Social Innovation and the Dialectical Relationship of State and Civil Society, „Urban Studies” 2005, vol. 42, http://usj.sagepub.com/content/42/11/2023 (dostęp 5.06.2015 r.), s. 2028. 
Warunkiem sine qua non jest uspołecznienie budżetu, osadzenie go we wspólnocie lokalnej. Konieczne jest zmobilizowanie szerokiego grona aktorów tego procesu, co z kolei wymaga właściwego rozpoznania lokalnych zasobów ludzkich ${ }^{25}$. Twórcy budżetu i władza lokalna powinna zdefiniować instytucje publiczne i ich przedstawicieli, organizacje pozarządowe, „ruchy miejskie” oraz nieformalne grupy społeczne jako potencjalnych uczestników przygotowania budżetu ${ }^{26}$. Lokacja budżetu w lokalnej społeczności wymaga edukacji obywatelskiej eksponującej korzyści nie tyle samego budżetu partycypacyjnego (choć są one bezsprzeczne), ile współpracy członków wspólnoty lokalnej z jej władzami. Bez stworzenia realnej bazy społecznej i rzeczywistego zainteresowania społecznego nie powstanie oddolny i trwały proces partycypacyjnego projektowania budżetu ${ }^{27}$.

Równie istotną przesłanką istnienia budżetu partycypacyjnego jest podniesienie poziomu merytorycznego procesu jego opracowywania. $\mathrm{W}$ tym celu konieczne wydaje się wypracowanie precyzyjnej metodologii sporządzania budżetu partycypacyjnego, ustalenia kręgu adresatów, rozważenie wpływu podziału terytorialnego miasta i stopnia rozwoju infrastrukturalnego na potrzeby lokalne, wzmocnienie organizacyjne i metodyczne oraz koordynacja procesu spotkań członków wspólnoty z władzą lokalną itd. Przydatne wydaje się powołanie zespołu koordynującego przygotowanie i przeprowadzenie budżetu partycypacyjnego oraz włączenie do jego zadań monitoringu budżetu partycypacyjnego w odniesieniu do efektów budżetów dotychczasowych, głosów niezadowolenia, ewentualnych modyfikacji procedury w następnym roku projektowym. Konieczne jest także wsparcie od strony prawnej, zwłaszcza że obywatele najczęściej nie znają prawnych uwarunkowań procesów inwestycyjnych. Trudności mogą się wiązać choćby z rozumieniem zasady superficies solo cedit.

Władza lokalna powinna też odpowiedzieć na pytanie o cel budżetu partycypacyjnego, gdyż jego konkretny kształt zawsze uwarunkowany jest sytuacją społeczną, polityczną i ekonomiczną danej społeczności lokalnej. Ma rację A. Rytel-Warzocha ${ }^{28}$, zwracając uwagę na różne funkcje,

25 B. Wampler, A guide do Participatory budgeting, 2000, https://www.commdev. org/userfiles/files/1613_file_GPB.pdf (dostęp 6.06.2015 r.), s. 7.

26 Proces uspołecznienia nie jest łatwy, co pokazuje przykład Porto Alegre w 1990 r. zaledwie 976 osób wzięło udział w zgromadzeniach publicznych (decydowano o 5\% budżetu miasta) w 2004 r. 50 tysięcy uczestników (przy tym nieoficjalne zgromadzenia - 600 tys. - aktywność grup sąsiedzkich, tworzących unię stowarzyszeń sąsiedzkich w Porto Alegre i organizacji).

27 Direct and Participatory Democracy at Grassroots Level: Levers for forging EU Citizenship and identity?, http://cor.europa.eu/en/documentation/studies/Documents/ direct-participatory-democracy.pdf (dostęp 6.06.2015 r.), s. 93.

28 A. Rytel-Warzocha, op. cit., s. 96. 
które spełnia ta forma uczestniczenia obywateli w sprawowaniu władzy. Przykładowo, doświadczenia niemieckie dowodzą, że stanowi ona sposób na unowocześnienie i usprawnienie procesów decyzyjnych, w Afryce mechanizmy te postrzegane są przede wszystkim jako element dobrej administracji, a w Hiszpanii i Wielkiej Brytanii jako narzędzie urzeczywistniania zasady sprawiedliwości społecznej. Każda z tych funkcji realizuje inne cele. Istotne jest więc, czy wspólnota lokalna ma dzięki budżetowi uzyskać więcej udogodnień w mieście, czy też próbować niwelować różnice infrastrukturalne w poszczególnych częściach lokalnego terytorium, czy może celem budżetu jest wyrównywanie szans bądź poprawa jakości życia.

Rola władz miejskich jest trudna do przecenienia, także gdy chodzi o pomoc w identyfikacji poszczególnych projektów do finansowania. Polskie doświadczenia ukazują, że zasadne mogłoby okazać się wcześniejsze sformułowanie projektów wymagających finansowania ${ }^{29}$, wybór członków społeczności lokalnej powinien zostać ograniczony.

Z budżetu Porto Alegre wynika jeszcze jedna ważna wskazówka dla naśladowców brazylijskiej koncepcji budżetu obywatelskiego. Można przyjąć, że konsultacyjny charakter budżetu jest niewystarczający dla zagwarantowania realnej partycypacji społecznej. Bez wprowadzenia mechanizmu decydowania funkcje budżetu zostaną zniekształcone. W Porto Alegre budżet partycypacyjny opieral się na współdecydowaniu członków społeczności. Uczestniczyli oni na wszystkich etapach przygotowania budżetu, debatowali nad hierarchią celów, merytorycznym znaczeniem projektu dla poszczególnych sfer życia społecznego, możliwościami jego wprowadzenia i skutkami jakie wynikały z jego realizacji. Proces przygotowania budżetu był długi, żmudny, defibracyjny i wiązał się z rzeczywistym i merytorycznym uczestnictwem w zarządzaniu miastem. W Polsce budżet obywatelski sprowadzany jest do konsultacji. Można wprawdzie oczekiwać, że propozycje ustalone przez członków wspólnoty zostaną zrealizowane $\mathrm{e}^{30}$, jednak często członkowie społeczności tylko zgłaszają projekty, a władzom lokalnym zależy wyłącznie na masowym uczestnictwie obywateli. W ten sposób dochodzi do fetyszyzacji głosowania, być może poprawy notowań, ale jednocze-

29 Jedną z inwestycji wybranych do realizacji w ramach łódzkiego budżetu obywatelskiego zostały szkolenia dla urzędników Zarządu Dróg i Transportu z zakresu metod ochrony i sadzenia drzew w strefie wielkomiejskiej. Na ten projekt oddano 245 głosów. Pomysł ten wywołał krytykę - zob. Szkolenia dla urzędników ZDiT, czyli... kpina z budżetu obywatelskiego, „Ekspres Ilustrowany”, 18 X 2015 r.

30 Zob. interesującą i przekonującą w tym względzie propozycję ujęcia budżetu partycypacyjnego w kategorii umowy społecznej - T. Dębowska-Romanowska, Budżet partycypacyjny. Drogi i rozdroża demokracji bezpośredniej, „Kronika Miasta Łodzi” 2013, nr 4. 
śnie do przygotowywania budżetu „na skróty” w sposób niedeliberacyjny i nieczasochłonny, jak miało to miejsce w Porto Alegre ${ }^{31}$.

Budżet partycypacyjny ma wiele zalet. Bezpośrednio poprawia jakość życia mieszkańców, sprzyja sprawiedliwemu podziałowi środków, poprawia zadowolenie $z$ usług publicznych, zwiększa odpowiedzialność za dobro wspólne, zaangażowanie w sprawy publiczne, a nawet włącza w życie publiczne osoby wykluczone. Ponadto, budżet ten poprawia wizerunek miasta i jego mieszkańców, zwiększa identyfikację mieszkańców z miastem, integruje mieszkańców wokół spraw publicznych, poprawia gospodarowanie środkami publicznymi, sprzyja zrównoważonemu rozwojowi dzielnic, jest praktyczną formą edukacji obywatelskiej i może przyczynić się do zwiększenia przejrzystości i wiarygodności władz lokalnych. Budżet partycypacyjny może pomóc $\mathrm{w}$ rozwoju społeczeństwa obywatelskiego rozwiązującego lokalne problemy rozwojowe ${ }^{32}$.

Recepcja budżetu partycypacyjnego nie powinna jednak ograniczać się jedynie do zainteresowania określonych grup członków społeczności lokalnej propozycjami projektów miejskich wartymi finansowania. Budżet partycypacyjny nie jest plebiscytem, lecz instrumentem demokratycznej deliberacji i ma sens tylko w przypadku właściwie wprowadzonych procedur, z uwzględnieniem podstawowych warunków zapewniających prawidłowe funkcjonowanie mechanizmu prowadzącego ku realnej zmianie społecznej. Nie wystarczy więc tylko nazwanie prima facie jakiejkolwiek procedury budżetem partycypacyjnym ${ }^{33}$.

31 Zob. krytyczną ocenę funkcjonowania budżetów partycypacyjnych w Polsce - B. Martela, Budżet partycypacyjny w Polsce - wdrożenie i perspektywy, http://cejsh. icm.edu.pl/cejsh/element/bwmeta1.element.desklight-80e82d42-f701-4c5e-8baa-21e885295160/c/budzet-partycypacyjny-w-polsce-wdrozenie-i-perspektywy.pdf (dostęp 6.06.2015 r.).

32 M. Burchard-Dziubińska, Budżet obywatelski jako partycypacyjna forma wspótrządzenia, „Zeszyty Naukowe Uniwersytetu Szczecińskiego. Studia i prace Wydziału Nauk Ekonomicznych i Zarządzania” 2014, nr 37, s. 199.

33 B. Martela, Ile partycypacji w budżecie obywatelskim?, http://www.partycypacjaobywatelska.pl /wydarzenie/141 (dostęp 23.10.2015). 


\section{Bibliografia}

Aragones E., Sanches-Pages S., A theory of participatory democracy based on the real case of Porto Alegre, „European Economic Review" 2008

Abers R., Porto Alegre and the Participatory Budget: Civic Education, Politics And The Possibilities For Replication, Paper prepared for the Carold Institute project "Building Local and Global Democracy" (2004-2006), http:// fimforum.org/en/library/Porto_Alegre_and_the_Participatory_Budget. pdf (dostęp 1-6.06.2015 r.).

Avritzer L., Sociedad civil, espacio público y poder local. Un análisis del presupuesto participativo en Belo Horizonte y Porto Alegre, [w:] Sociedad civil, esfera pública y democratización en América Latina: Brasil, red. Dagnino E., Mexico 2002.

Avritzer L., Democracy and the public space in Latin America, Princeton 2002.

Avritzer L., Models of democratic deliberation: participatory budgeting in Brazil, [w:] Democratizing democracy: beyond the liberal democratic canon, red. de Sousa Santos B., New York 2006.

Avritzer L., Participatory Institutions in Democratic Brazil, Baltimore 2009.

Baiocchi G., Militants and citizens: the politics of participation in Porto Alegre, Stanford 2005.

Burchard-Dziubińska M., Budżet obywatelski jako partycypacyjna forma wspótrządzenia, „Zeszyty Naukowe Uniwersytetu Szczecińskiego. Studia i prace Wydziału Nauk Ekonomicznych i Zarządzania” 2014, nr 37.

Chavez Miños D., Porto Alegre, Brazil: A new, sustainable and replicable model ofparticipatory and democratic governance?, dostępne na http://ibrarian.net/navon/paper/ Daniel_Chavez_Mi_os. pdf?paperid=5644680 (dostęp 1-6.06.2015 r.).
Cleuren $\mathrm{H}$, Administrating participatory budgeting in Porto Alegre. Street level officials and organisational preconditions, "Estado, Gobierno, Gestión Publica, Revista Chilena de Administración Publica" No.

Diciemnre 2008, http://www.dialnet.unirioja.es/descarga/articulo/2932574. pdf (dostęp 1-6 062015 r.).

Direct and Participatory Democracy at Grassroots Level: Levers for forging EU citizenship and identity?, http:// cor.europa.eu/en/documentation/ studies/Documents/direct-participatory-democracy.pdf (dostęp 1-6. 06.2015 r.).

Dębowska-Romanowska T., Budżet partycypacyjny. Drogi i rozdroża demokracji bezpośredniej, „Kronika Miasta Łodzi" 2013, nr 4.

Giddens A., Runaway World. How Globalization Is Reshaping our Lives, New York 2000, cyt. za: R. Zenderowski, Czy globalizacja unieważni nacjonalizmy i tożsamości narodowe?, „Studia Bobolanum" 2011, nr 1.

Jabłońska B., W stronę demokracji deliberacyjnej? O politycznym komunikowaniu na tematy europejskie w polskiej prasie,

KłębowskiW., Budżet partycypacyjny krótka instrukcja obsługi, http:// www.instytutobywatelski.pl (dostęp 1-6.06.2015 r.).

Koonings K., Strengthening citizenship in Brazil's democracy: Local participatory governance in Porto Alegre, „Bulletin of Latin America Research" 2004, vol. 23, http://www.chs. ubc.ca/participatory/docs/Koonings\%28A\%29. pdf (dostęp 1-6.06.2015 r.).

Koryanov I., Sisk T.D., Participatory democracy, [w:] Democracy At The Local Level, A Guide for the South Caucasus, http://iknowpolitics. org/ sites/default/files/democracy-locallevel-southcaucus. pdf (dostęp 1-6. 06.2015 r.). 
Marquetti A., Schonerwald de Silva C.E.,Campbell A., Participatory Economic Democracy in Action: Participatory Budgeting in Porto Alegre, 1989-2004, http://content.csbs. utah.edu/ al/articles/Sub_PB1.pdf (dostęp 1-6.06.2015 r.).

Martela B., Budżet partycypacyjny w Polsce - wdrożenie i perspektywy, http:// cejsh.icm.edu.pl/cejsh/element /bwmeta1.element.desklight-80e82d42-f701-4c5e-8baa-21e8 $85295160 /$ c/budzet-partycypacyjnyw-polsce-wdrozenie-i-perspektywy. pdf (dostęp 1-6.06.2015 r.).

Martela B., Ile partycypacji w budżecie obywatelskim?, http://www.partycypacjaobywatelska.pl /wydarzenie/141 (dostęp 1-6.06.2015 r.).

Novy A., Leubolt B., Participatory Budgeting in Porto Alegre: Social Innovation and the Dialectical Relationship of State and Civil Society, „Urban Studies" 2005, vol. 42, http://usj.sagepub.com/content/42/11/2023 (dostęp 1-6.06.2015 r.).

Piotrowski P., Globalizacja i konstytucja, „Zagadnienia Sądownictwa Konstytucyjnego" 2012.

N. A. Report on the CDLR survey of the role of central/regional government in participatory budgeting at local level.

Legal framework and current practice in memberstates, 17 October 2011, https:// wcd.coe.int/com.instranet.InstraServlet?command=com.instranet.CmdBlobGet\&InstranetImage $=2567401 \&$ SecMode $=1 \&$ Docld $=1801348 \&$ Usage $=2$, (dostęp 1-6.06 2015 r.).
Rytel-Warzocha A., Partycypacja społeczna w sprawach budżetowych. Model Porto Alegre jako pierwowzór rozwiqzań europejskich, „Przegląd Prawa Konstytucyjnego" 2007, nr 1, s. 97.

Sintomer Y., Herzberg C., Röcke A., Participatory Budgeting in Europe: Potentials and Challenges, „International Journal of Urban and Regional Research" 2008, vol. 321.

Szkolenia dla urzędników ZDiT, czyli... kpina z budżetu obywatelskiego, „Ekspres Ilustrowany” 18 X 2015 r.

Szostak W., Globalizacja a suwerennośc państwa współczesnego, [w:] Nowoczesny Lewiatan. Studia nad wspótczesnym państwem, red. Kornaś J., Kielce 2006.

Wampler B., Orçamento Participativo: uma explicação para as amplas variaçoes nos resultados, [w:] A inovação democratica no brasil, red. Avritzer L., Navarro Z., São Paulo.

Wampler B., Avritzer L., The Spread of Participatory Budgeting in Brazil: From Radical Democracy to Participatory Good Government, „Journal Of Latin American Urban Studies", New York, v. 7, Fall, s. 37-52.

Wampler B., Participatory Budgeting in Brazil: contestation, cooperation, and accountability, Pennsylvania State University Press 2008.

Wampler B., A guide do Participatory budgeting, October 2000, https://www. commdev.org/userfiles/files/1613_ file_GPB.pdf (dostęp 1-6.06.2015 r.). 